\title{
STRATEGI PEMIMPIN POPULIS BARU INDONESIA MENCAPAI KEKUASAAN
}

\author{
Imelda Masni Juniaty Sianipar \\ imelda.sianipar@uki.ac.id \\ Fakultas Ilmu Sosial dan Ilmu Politik Universitas Kristen Indonesia
}

\begin{abstract}
Indonesia has already had a populist leader, Ir. Soekarno. He is the first President of the Republic Indonesia. Sukarno is categorized as a populist leader because He is charismatic and close to the people. In 2014, Indonesia has witnessed the presence of populist leader in national political arena. The new populist leader is Joko Widodo or who is wellknown as Jokowi. This figure was chosen by the majority of the people of Indonesia as a president because it was believed that Jokowi has a populist style leadership. He is also close to the people. This paper will specifically explain Jokowi's strategies as a new populist leader in order to gain power. This paper argues that in order to gain power and also to get the support from Indonesian people, Jokowi relies on his organizational experiences, skills, leadership and achievements. $\mathrm{He}$ also built a coalition with organized society especially with PDI-P participant and also unorganized society who is known as Relawan Jokowi. The last strategy of Jokowi is to promote demand policy oriented. Based on those strategies, this paper categorizes Jokowi as a rational populist leader.
\end{abstract}

Keywords: populist leader, Jokowi, power, Indonesia, rational populism.

\begin{abstract}
Abstrak
Indonesia pernah memiliki pemimpin populis yaitu Ir. Soekarno, Presiden Pertama Republik Indonesia. Soekarno dikategorikan sebagai pemimpin populis karena memiliki gaya kepemimpinan yang kharismatik dan dekat dengan rakyat. Pada tahun 2014, Indonesia kembali menyaksikan hadirnya pemimpin populis di kancah perpolitikan nasional. Pemimpin populis baru tersebut adalah Joko Widodo atau akrab dikenal dengan Jokowi. Tokoh ini dipilih oleh mayoritas rakyat Indonesia sebagai presiden karena diyakini memiliki karakter kepemimpinan populis dan dekat dengan rakyat. Tulisan ini secara khusus akan membahas strategi Jokowi sebagai pemimpin populis Indonesia baru dalam rangka mencapai kekuasan. Tulisan ini berargumen bahwa Jokowi mengandalkan pengalaman organisasi, skill dan leadership dan prestasi yang dimilikinya, membangun koalisi baik dengan masyarakat terorganisir maupun yang tidak terorganisir serta mengedepankan kebijakan yang berorientasi pada demand (tuntutan) dalam rangka mendapatkan dukungan rakyat untuk mencapai kekuasaan. Karenanya, Tulisan ini mengkategorikan Jokowi sebagai pemimpin populis rasional.
\end{abstract}

Kata kunci: pemimpin populis, Jokowi, kekuasaan, Indonesia, populisme rasional

\section{Pendahuluan}

Pada pemilihan umum Presiden dan Calon Presiden Republik Indonesia yang diadakan pada bulan Juli 2014 lalu, Joko Widodo dan Jusuf Kala terpilih sebagai presiden dan wakil presiden Republik Indonesia untuk periode 2014-2019. Joko Widodo - Jusuf
Kala memperoleh suara sebesar 53,5 \%, sementara pesaingnya Prabowo Subianto-Hatta Rajasa mendapat suara sebesar 46,85\%. Mayoritas rakyat Indonesia memilih Jokowi karena Jokowi diyakini merupakan pemimpin populis yaitu pemimpin yang peduli pada rakyat kecil. 
Munculnya Jokowi sebagai pemimpin populis baru Indonesia merupakan sebuah fenomena yang unik. Pasalnya, Jokowi hanyalah orang biasa yang berasal dari kalangan bawah. Jokowi bukan keturunan bangsawan, bukan konglomerat, bukan ketua umum partai politik dan bukan mantan Jenderal. Jokowi tidak memiliki kharisma tertentu yang dapat membuat masyarakat mengaguminya. Bahkan, Jokowi tidak memiliki sebuah ideologi tertentu yang bisa ditawarkan sebagai alternatif pilihan. Kemampuan Jokowi sebagai politisi pun masih diragukan karena latar belakang pekerjaan beliau yang hanyalah seorang pengusaha mebel yang notabenenya tidak berkaitan dengan urusan-urusan politik.

Sebagai orang biasa yang tidak memiliki kharisma atau modal tertentu bukanlah hal yang mudah untuk mendapatkan dukungan dalam rangka mencapai kekuasaan. Berdasarkan fakta tersebut maka tulisan ini secara khusus akan membahas tentang strategi yang ditempuh oleh Jokowi dalam rangka mencapai kekuasaan tersebut.

\section{Definisi Populisme}

Populisme merupakan sebuah istilah yang masih diperdebatkan oleh para sarjana. Berdasarkan pengalaman yang terjadi di benua Amerika Latin pada 1940-1960an, populisme diiidentikkan dengan rezim personalistik yang berkembang pesat ditengah-tengah masyarakat dimana perkembangan organisasi dan institusi telah dilumpuhkan. Banyak sarjana dan analis beranggapan bahwa istilah populisme merujuk pada gaya rejim dimana pemimpin politiknya menggunakan gaya personalistik. Istilah populisme (populis dalam bahasa latin) berarti sebuah gerakan, sebuah rejim, seorang pemimpin atau bahkan sebuah negara yang mengklaim memiliki kedekatan dengan rakyat.

Allan Knight (1998) berpendapat bahwa populisme merupakan sebuah gaya politik khusus yang memperlihatkan adanya kedekatan hubungan dengan rakyat. Kenneth M. Roberts (2007) menyatakan bahwa populisme merupakan mobilisasi politik massa dari atas ke bawah yang dilakukan oleh pemimpin personalistik untuk menentang sekelompok elit dengan mengatasnamakan penderitaan rakyat (the top-down political mobilization of mass constituencies by personalistic leaders who challenge elite groups on behalf of an illdefined pueblo, or "the people"). Sedangkan Kurt Weyland (2001) berargumen bahwa populisme adalah strategi politik yang digunakan oleh pemimpin populis untuk mencapai kekuasaan dengan melakukan kontak langsung dengan massa yang tidak terorganisir (a political strategy through which a personalistic leader seeks or exercises government power based on direct, unmediated uninstitutionalized support from large numbers of mostly unorganized followers). Berdasarkan definisi Knight, Roberts dan Weyland tersebut nampak jelas bahwa populisme merupakan strategi yang digunakan oleh pemimpin untuk mencapai kekuasaan baik itu sebagai gaya politik maupun sebagai model penggerakan (mobilisasi) massa.

\section{Varian Populisme}

Dalam rangka mencapai kekuasaan tersebut, para pemimpin populis menggunakan berbagai strategi. Berdasarkan strategi yang digunakan, populisme dapat dibedakan menjadi dua varian yaitu populisme irasional dan populisme rasional (Imelda, 2011: 49-52). Dalam populisme irasional, pemimpin populis menggunakan kharisma dan ideologi untuk menghipnotis 
masyarakat atau pengikutnya. Pemimpin populis irasional tidak memiliki basis kekuatan politik yang kuat. Pengikutnya adalah kumpulan masyakarat kelas bawah yang pernah kecewa, terabaikan dan termarginalkan oleh pemimpin sebelumnya. Karenanya, ikatan antara pemimpin populis irasional dan pengikutnya lemah. Untuk memperkuat hubungan antara pemimpin dan pengikutnya tersebut, pemimpin populis irasional akan memberikan uang, hadiah, subsidi dan proteksi kepada para pengikutnya.(ibid)

Sementara itu, pemimpin populis dalam varian populisme rasional akan mengandalkan prestasi, kemampuan leadership, skill yang dimilikinya untuk mendapatkan dukungan dari masyarakat. Pemimpin populis rasional telah memiliki basis kekuatan politik yang kuat. Pendukungnya merupakan masyarakat yang kritis dan rasional karenanya pemimpin populis juga dituntut untuk bertindak rasional. Pemimpin tidak boleh hanya mengumbar janji-janji saja tetapi harus merealisasikan janji-janji kampanyenya tersebut supaya tetap mendapat dukungan dari masyarakat. Pemimpin populis rasional akan berupaya untuk membantu masyarakat kelas bawah memiliki kemampuan daya beli (demand) sehingga mereka dapat memenuhi kebutuhan hidupnya. Hal tersebut dapat dilakukan antara lain dengan menciptakan lapangan pekerjaan atau meningkatkan kualitas pendidikan masyarakat kelas bawah sehingga masyarakat kelas bawah memiliki kemampuan untuk bersaing di pasar (Ibid). Untuk memperjelas pemahaman mengenai populisme irasional dan populisme rasional, lihat Tabel 1.

\section{Tabel 1}

Populisme Irasional dan Populisme Rasional

\begin{tabular}{lll}
\hline Populisme & Irasional & Rasional \\
\hline $\begin{array}{l}\text { Karakter } \\
\text { Kepemimpinan }\end{array}$ & $\begin{array}{l}\text { Mengandalkan } \\
\text { kharisma dan } \\
\text { ideologi }\end{array}$ & $\begin{array}{l}\text { Mengandalkan } \\
\text { "Track Record" } \\
\text { (keahlian } \\
\text { leadership dan } \\
\text { pengalaman } \\
\text { organisasi) }\end{array}$ \\
\hline $\begin{array}{l}\text { Pola } \\
\text { Aliansi/Koalisi }\end{array}$ & $\begin{array}{l}\text { Kelas Atas yang } \\
\text { lemah }\end{array}$ & $\begin{array}{l}\text { Kelas Atas yang } \\
\text { kuat dan Kelas } \\
\text { Bawah yang } \\
\text { relatif kuat dan } \\
\text { terorganisir } \\
\text { dengan baik }\end{array}$ \\
& $\begin{array}{l}\text { Kelas Bawah } \\
\text { yang lemah dan } \\
\text { tidak } \\
\text { terorganisir } \\
\text { dengan baik }\end{array}$ & \\
\hline $\begin{array}{l}\text { Kebijakan } \\
\text { kesejahteraan }\end{array}$ & $\begin{array}{l}\text { Bagi-bagi } \\
\text { hadiah atau } \\
\text { rezeki }\end{array}$ & $\begin{array}{l}\text { Menggunakan } \\
\text { ekonomi dari } \\
\text { sisi demand }\end{array}$ \\
\hline
\end{tabular}

Sumber: Imelda, 2011: 49-52

\section{Track Record Jokowi}

$$
\text { Joko Widodo merupakan }
$$
seorang tokoh yang muncul dari kalangan bawah menuju pentas politik nasional. Jokowi bukan keturunan bangsawan, bukan konglomerat, bukan ketua umum partai serta bukan seorang mantan Jenderal. Lalu apa yang membuat Jokowi menjadi popular bahkan kepopulerannya melebihi popularitas ketua umum partai pendukungnya, PDI-P Perjuangan, yaitu Megawati Soekarnoputri.

Pada awal keterlibatannya dalam politik, banyak orang meragukan kemampuan Jokowi. Awalnya, Jokowi adalah seorang pengusaha furniture / mebel yang kemudian memutuskan untuk mencalonkan diri sebagai walikota Solo dengan mengendarai Partai Politik PDI-P pada tahun 2005. Selama kepimimpinannya, kota Solo banyak mengalami kemajuan. Jokowi berhasil mengembangkan Solo yang 
buruk penataannya menjadi maju dan berkembang dan bahkan menjadikan Solo sebagai kajian di universitas luar negeri. Ide penataan kota Solo tersebut terinspirasi oleh pengamatannya terhadap pengembangan kota-kota di Eropa yang dikunjungi dalam rangka perjalanan bisnisnya. Pada Tahun 2006, Jokowi mengajukan Surakarta (Solo) menjadi anggota Organiasasi Kota-kota warisan Dunia. Selanjutnya, Jokowi juga menjadikan Surakarta (Solo) sebagai Tuan Rumah Konferensi Organiasasi Kota-kota warisan Dunia pada Oktober 2008 (www.pemilu.com).

Keberhasilan Jokowi mengembangkan kota Solo pada 2005-2012 mendorong PDI-P mencalonkan Jokowi sebagai kandidat gubernur DKI Jakarta bersama dengan Basuki Tjahaja Purnama. Setelah melalui pemilihan 2 putaran pasangan Jokowi-Basuki berhasil menjadi Gubernur dan Wakil Gubernur DKI Jakarta mulai dari 15 Oktober 2012. Di Jakarta yang merupakan ibukota negara Republik Indonesia tersebut, Jokowi kembali memperlihatkan prestasinya. Jokowi melakukan berbagai penataan terhadap kota Jakarta antara lain dengan merelokasi warga di Waduk Ria Rio Pulogadung, Jakarta Timur, ke Rumah Susun Sewa (Rusunawa) Pinus Elok, Cakung (news.liputan6.com) dan warga sekitar Waduk Pluit, Penjaringan, Jakarta Utara ke Rusun Marunda (megapolitan.kompas.com) Jokowi melakukan pembenahan transportasi umum Jakarta dengan meresmikan pembangunan Angkutan Massal Cepat (MRT) yang sebelumnya sempat tertunda selama bertahun-tahun dan pembangunan jalur hijau Monorel Jakarta sepanjang sebelas kilometer. Jokowi juga berencana untuk mengadakan seribu bus untuk jalur bis Transjakarta untuk mencukupi kebutuhan transportasi masyarakat
Jakarta (microsite.metrotvnews.com). Untuk memperbaiki kesehatan dan pendidikan, Jokowi meluncurkan program Kartu Jakarta Sehat dan Kartu Jakarta Pintar. Kartu Jakarata Sehat memungkinkan masyarakat DKI Jakarta mendapat pelayanan paling dasar tanpa harus mengeluarkan uang banyak, sementara Kartu Jakarta Pintar adalah program terseleksi bagi murid yang tidak mampu agar mampu membeli peralatan dan kebutuhan pendidikan (Ibid).

Prestasi demi prestasi yang dibuat oleh Jokowi menyebabkan popularitas Jokowi semakin meningkat. Hal ini memunculkan gagasan dari kelompok masyarakat tertentu untuk memajukan Jokowi sebagai calon Presiden RI pada Pemilu 2014. Berdasarkan survey CSIS yang dilakukan dengan wawancara tatap muka terhadap 1.180 responden di 33 provinsi pada 13-20 November 2013, dukungan yang menginginkan Jokowi menjadi presiden datang dari berbagai pihak. Pendukung Jokowi terbesar masih berasal dari PDI-P yaitu sebesar 63,6\%, Partai Demokrat sebesar 42,7\%, Partai Golkar sebesar 22,7\% dan Partai Gerindra sebesar 20,6\%. Menurut Philips J. Vermonte (nasional.kompas.com), ada satu hal yang menarik dari hasil survey tersebut. Pertama, pendukung Jokowi berasal dari lintas partai. Kedua, dukungan terhadap Jokowi mengalahkan dukungan terhadap Ketua Umum PDI-P yaitu Megawati Soekarno Poetri. Melihat kenyataan ini, PDI-P hanya mempunyai satu pilihan yaitu mencalonkan Jokowi sebagai calon presiden RI pada Pilpres 2014.

Menurut Marcus Meitzner, peneliti politik Indonesia di Australian National University (tempokini.com), Jokowi menjadi tokoh dan idola 
masyarakat karena mampu merebut hati masyarakat yang kecewa terhadap kepemimpinan Susilo Bambang Yudhoyono (SBY) dalam periode kedua kepemimpinannya. SBY sebagai presiden yang sebelumnya diharapkan mampu membawa gerbong reformasi menuju perbaikan kehidupan berbangsa dan bernegara mengalami kemunduran popularitas karena di era kepemimpinannya sarat dengan kasus korupsi. SBY dipandang sibuk membangun citra melalui berbagai media, dan kepemimpinan SBY dianggap semakin menjauh dari masyarakat. Masyarakat memperoleh jawaban dari fenomena gaya kepemimpinan Jokowi yang berempati, dekat dengan rakyat dan tidak bekerja di belakang meja.

Kemerosostan popularitas SBY di periode kedua kepemimpinannya sebenarnya memberi peluang besar bagi partai politik maupun elit politik nasional untuk memunculkan calon presiden alternatif. Adapun calon presiden alternatif tersebut antara lain adalah Megawati, Prabowo Subianto dan Aburizal Bakrie. Dari ketiga calon tersebut, Prabowo Subianto dianggap sebagai figur yang layak menggantikan popularitas SBY dan diprediksi memiliki peluang besar untuk menang pemilihan presiden karena Prabowo memiliki gaya kepemimpinan tegas yang mampu menggantikan gaya kepemimpinan SBY yang dipandang tidak tegas. Namun demikian, Prabowo memiliki beberapa kelemahan. Masyarakat meragukan kredibilitas Prabowo karena selain merupakan bagian masa lalu dan memiliki kedekatan dengan penguasa orde baru, juga dianggap terlibat pelanggaran Hak Azasi Manusia dan diberhentikan dari militer (Ibid).

Pendapat Meitzner tersebut sejalan dengan Christian Von Lübke (Ibid) yang merupakan Peneliti Senior
Fellow Departemen Ilmu Politik Universitas Freiburg. Von Lübke berpendapat bahwa kehadiran Jokowi ke pentas politik nasional merupakan jawaban terhadap kerisauan dan apatisme masyarakat terhadap praktek politik selama ini yang sarat dengan kasus-kasus pelanggaran hukum publik dan korupsi. Kehadiran Jokowi menuju puncak kekuasaan presiden Indonesia merupakan sebuah tanda munculnya pemimpin responsif dan partisipatif.

Von Lübke mengamati paling tidak ada tiga aset politik yang dimiliki oleh Jokowi yang dapat berkontribusi dalam meningkatkan popularitasnya. Aset politik pertama adalah Jokowi bukan berasal dari lingkaran penguasa masa lalu (Oligarki) sehingga Jokowi memiliki keleluasan menjadi pemimpin reformis. Jokowi bisa menjadi pemimpin bersifat pluralis melampaui batas-batas etnis, ekonomi dan administrasi. Jokowi memungkinkan menjadi pemimpin inklusif dan kurang partikularistik dalam membuat kebijakan. Aset politik kedua yang dimiliki Jokowi adalah keberhasilannya meluncurkan reformasi masyarakat luas. Jokowi mampu membuat keseimbangan portofolio kebijakan yang seimbang antara kepentingan masyarakat kecil dengan kepentingan pengusaha besar. Contohnya adalah seperti yang dilakukannya di Solo. Jokowi melakukan relokasi pedagang kaki lima menjadi pedagang formal dan memiliki tempat yang layak di pasar tradisional Solo sehingga pendapatan mereka meningkat. Pada saat yang sama, Jokowi juga memberi peluang bagi pembangunan hotel, apartemen dan hadirnya bisnis ritel seperti Solo Paragon, Center Point, Kusuma Tower dan Solo Square. Jokowi juga berhasil memperbaiki kinerja bawahannya dan menekan inefisiensi serta korupsi di dalam birokrasi. Kemampuan Jokowi 
untuk memediasi berbagai kepentingan, mengurangi birokrasi administrasi dan menciptakan peluang ekonomi baru telah melambungkan nama Jokowi ke pentas politik nasional maupun internasional dan memperkuat citranya sebagai pemimpin yang responsif dan reformis, sehingga menerima penghargaan dari Kementerian Dalam Negeri 'Walikota Terbaik' pada tahun 2011, tampil sebagai runner-up untuk 'World Mayor Prize' di awal tahun 2012 dan terpilih menjadi gubernur Jakarta pada September 2012 (Ibid).

Aspek ketiga yang berkontribusi untuk meningkatkan popularitas Jokowi adalah gaya kepemimpinan partisipatifnya. Dalam membuat keputusan Jokowi terlebih dahulu akan mendengarkan semua kalangan. Jokowi sabar membujuk dan bernegosiasi. Kegemaran Jokowi untuk blusukan ke lapangan juga telah menghipnotis masyarakat dan elit politik dan membangkitkan antusiasme masyarakat untuk mengidolakannya.

\section{Koalisi Pendukung Jokowi}

Dalam rangka mencapai kekuasaan, Jokowi menggunakan partai politik sebagai kendaraannya menuju panggung perpolitikan. Partai politik utama pendukung Jokowi adalah PDI-P. Selanjutnya, Jokowi mendapat dukungan dari Partai Nasional Demokrat (Nasdem) dan Partai Kebangkitan Bangsa (PKB). Di penghujung pelaksanaan pemilu, Partai Hati Nurani Rakyat (Hanura) akhirnya turut juga memberi dukungan kepada Jokowi. Meskipun Jokowi telah mendapat dukungan dari beberapa partai politik besar, Jokowi masih membutuhkan dukungan lainnya. Dukungan tersebut akhirnya diperoleh dari masyarakat bukan kader yang menamakan diri mereka sebagai relawan Jokowi. Berdasarkan fakta tersebut maka dapat dikatakan bahwa dalam rangka mencapai kekuasaan, Jokowi membangun koalisi tidak hanya dengan partai politik tetapi juga dengan simpatisan atau yang dikenal relawan Jokowi yang umumnya terdiri dari masyarakat menengah ke bawah.

\section{Partai Politik Pendukung Jokowi}

Dalam rangka memenangkan pemilihan umum, Jokowi mengandalkan partai politik sebagai kendaraannya. PDI-P merupakan partai politik pendukung utama Jokowi. PDI-P kemudian membangun koalisi dengan Partai Nasional Demokrat (Nasdem) dan Partai Kebangkitan Bangsa (PKB). Koalisi ketiga partai tersebut yaitu PDI Perjuangan (18,95\%), Partai Nasional Demokrat $(6,7 \%)$ dan Partai Kebangkitan Bangsa (9,04 \%) menghasilkan kekuatan suara sebesar 34,06 \% dan memperoleh sebanyak 191 kursi di Dewan Perwakilan Rakyat (DPR) (lihat tabel 2 dan 3).

Sementara itu, kekuatan partai pengusung Prabowo Subianto-pesaing Jokowi terdiri dari Partai Gerindra $(11,81 \%)$, Partai Persatuan Pembangunan $(6,53 \%$, Partai Keadilan Sejahtera $(6,7 \%)$, dan Partai Amanat Nasional (7,59 \%). Koalisi empat partai tersebut akan menghasilkan suara sebesar 31,63 \% dan memperoleh 201 kursi (lihat tabel 2 dan 3).

Tabel 2 memperlihatkan perolehan suara 12 parpol dan pemenuhan ambang batas (parliamentary treshold) 3,5 persen berdasarkan perhitungan tetap Komisi Pemilihan Umum. Tabel 3 merupakan hasil per-hitungan pada data rekapitulasi yang ditetapkan KPU dan penetapan di atas, berikut prediksi perolehan kursi 10 partai politik yang lolos ke Senayan. 
Tabel 2

Perolehan suara 12 parpol berdasarkan perhitungan tetap KPU

\begin{tabular}{llrr}
\hline No. & \multicolumn{1}{c}{ Partai } & $\begin{array}{c}\text { Jumlah } \\
\text { Suara }\end{array}$ & Persentase \\
\hline $\mathbf{1}$ & Nasdem & 8.402 .812 & $(6,7 \%)$ \\
\hline $\mathbf{2}$ & PKB & 11.298 .957 & $(9,04 \%)$ \\
\hline $\mathbf{3}$ & PKS & 8.480 .204 & $(6,7 \%)$ \\
\hline $\mathbf{4}$ & PDIP & 23.681 .471 & $(18,95 \%)$ \\
\hline $\mathbf{5}$ & Golkar & 18.432 .312 & $(14,75 \%)$ \\
\hline $\mathbf{6}$ & Gerindra & 14.760 .371 & $(11,81 \%)$ \\
\hline $\mathbf{7}$ & Demokrat & 12.728 .913 & $(10,19 \%)$ \\
\hline $\mathbf{8}$ & PAN & 9.481 .621 & $(7,59 \%)$ \\
\hline $\mathbf{9}$ & PPP & 8.157 .488 & $(6,53 \%)$ \\
\hline $\mathbf{1 0}$ & Hanura & 6.579 .498 & $(5,26 \%)$ \\
\hline $\mathbf{1 1}$ & PBB & 1.825 .750 & $(1,46 \%)$ \\
\hline $\mathbf{1 2}$ & PKPI & 1.143 .094 & $(0,91 \%)$ \\
\hline & & \multicolumn{3}{c}{ Sumber: news.detik.com }
\end{tabular}

Tabel 3

Perolehan kursi 10 partai politik

\begin{tabular}{lll}
\hline No. & Nama Partai & Jumlah Kursi \\
\hline $\mathbf{1}$ & PDIP & 109 Kursi \\
\hline $\mathbf{2}$ & Golkar & 91 Kursi \\
\hline $\mathbf{3}$ & Gerindra & 73 Kursi \\
\hline $\mathbf{4}$ & Demokrat & 61 Kursi \\
\hline $\mathbf{5}$ & PAN & 49 Kursi \\
\hline $\mathbf{6}$ & PKB & 47 Kursi \\
\hline $\mathbf{7}$ & PKS & 40 Kursi \\
\hline $\mathbf{8}$ & PPP & 39 Kursi \\
\hline $\mathbf{9}$ & NasDem & 35 Kursi \\
\hline $\mathbf{1 0}$ & Hanura & 16 Kursi \\
\hline \multicolumn{2}{c}{ Total } & 560 Kursi \\
\hline & \multicolumn{2}{c}{ Sumber: news.detik.com }
\end{tabular}

Berdasarkan data pada Tabel 2 dan Tabel 3 nampak jelas bahwa di DPR periode 2014-2019, koalisi partai pendukung Prabowo memiliki jumlah kursi lebih banyak dibandingkan dengan koalisi partai pendukung Jokowi. Karenanya, jika Jokowi terpilih sebagai presiden, besar kemungkinan kedua koalisi ini akan beradu kekuatan.

\section{Relawan Jokowi}

Dalam rangka mencapai kekuasaan, Jokowi tidak hanya bersandar pada dukungan dari partai politik pendukungnya tetapi juga dari masyarakat-masyarakat yang menyatakan diri sebagai relawan Jokowi. Masyarakat ini bukanlah kader maupun simpatisan dari PDI-P. Mereka secara spontan membentuk komunitas untuk mencalonkan Jokowi sebagai Presiden. Mereka pada umumnya adalah masyarakat yang berasal dari kalangan menengah ke bawah terdiri dari masyarakat petani, masyarakat nelayan, pedagang kaki lima, dan lainlain.

Di Aceh, tim relawan Jenggala Center mendeklarasikan diri mendukung Jokowi sebagai calon Presiden 2014. Deklarasi tersebut dilakukan di depan sekretariat Jenggala yang berada di Jalan Loeng. Deklarasi ini merupakan deklarasi perdana di Aceh untuk mendukung pasangan calon Presiden dan Wakil Presiden Jokowi-JK. Menurut H. Sayed Fuad Zakaria yang merupakan koordinator relawan Jenggala Aceh dan juga anggota DPR RI dari partai Golkar, tim Jenggala Center Aceh adalah tim relawan yang langsung dibentuk oleh Jusuf Kalla dan seluruh Surat Kerja (SK) yang diberikan kepada relawan langsung berasal dari Jusuf Kalla. Tim ini mendukung pencalonan Jokowi-JK karena Jokowi dianggap sebagai orang yang merakyat dan Jusuf Kalla dianggap sebagai orang yang sangat berjasa bagi Perdamaian Aceh. Berkat peran aktif Jusuf Kalla pada masa penjajakan, perdamaian RI dengan GAM bisa diwujudkan pada tanggal 15 Agustus 2005 di Helsinki, Finlandia (aceh.tribunnews.com).

Di Medan, berbagai relawan menyatakan diri mendukung Jokowi 
(medan.tribunnews.com). Relawanrelawan ini datang dari berbagai elemen masyarakat, mulai dari petani sampai buruh. Paling tidak terdapat 40 relawan Jokowi yang tersebar di Sumatera Utara. Ke-40 relawan tersebut adalah Relawan Bara JP Provinsi Sumut; Relawan Bara JP Membara; Relawan Cakra Provinsi Sumut; Relawan Forum Jokowi Presiden Sumut; Relawan Laskar Rakyat Jokowi Sumut; Relawan Sahabat Jokowi Sumut; Relawan Seknas Jokowi Sumut; Relawan Seknas UKM Sumut; Relawan Forum India Sumut; Relawan Kawan Jokowi Sumut; Relawan Best (Black Eagle Squad Team) Sumut; Relawan Pergerakan Kebangkitan Nasional Indonesia Sumut; Relawan Gotong Royong Sumut; Forum Relawan Jokowi Sumut; Relawan Simpul Masyarakat Jokowi (Si Mas); Relawan Simpatisan Jokowi; Relawan Posko Perjuangan Rakyat; Relawan Buruh Bersatu Mendukung Jokowi (BBM); Relawan Serbu Jokowi-JK; Relawan Cinta Jokowi; Posko Relawan Tali Kasih Jokowi-Jusuf Kalla; Relawan Pos Pera Sumut; Relawan Kampung Jokowi-Jusuf Kalla; Relawan Forum Rakyat Peduli Kesehatan; Komunitas Sarjana Sumatera Utara; Relawan Pro Jokowi (Pematangsiantar); Relawan Pendukung Jokowi-Jusuf Kalla (Penjola); Relawan Pendukung Jokowi-Jusuf Kalla; Gerakan Mahasiswa Relawan Jokowi (Gemar); Relawan Aliansi Masyarakat Sipil Untuk Indonesia Hebat (Almisbat); Relawan Komunitas Ahab Untuk Jokowi; Relawan Peduli Kasih Pendukung Jokowi-JK; Relawan Mutiara Jokowi; Famili's Relawan Jokowi; Relawan Elemen Nusantara (Elnusa) Jokowi-JK; Aliansi Masyarakat Adat Nasional Sumut; Komite Aksi Korban Pelanggaran HAM Tahun 1965; LLP HAM Nusantara Medan; Relawan Rakyat Jokowi dan Keluarga Perkumpulan Warung Kopi.
Selain di Sumatera Utara, di Dumai, Riau pun terdapat relawan pendukung Joko Widodo. Mereka berasal dari non partai politik. Hampir seribu orang warga pendukung siap dan berkomitmen memenangkan Jokowi. Menurut Ketua Gerakan Masyarakat Dumai untuk Jokowi, Benny Akbar, masyarakat non partisan partai politik di Dumai berpandangan sama terhadap calon presiden yang diharapkan, sehingga disepakati siap berjuang memenangkan Jokowi. Jokowi dinilai sebagai rakyat biasa yang menghendaki adanya perubahan dalam kehidupan berbangsa dan bermasyarakat dinilai tepat untuk memimpin Indonesia lima tahun ke depan. Pembentukan relawan pro Jokowi-JK di Dumai ini berawal dari bincang-bincang sesama dan akhirnya menyatukan suara dan tekad untuk meletakkan tonggak kepemimpinan negara kepada capres tersebut. Mereka percaya dan menaruh harapan besar kepada Jokowi-JK agar memenangkan kompetisi untuk Indonesia yang lebih maju dan sejahtera. Menurut Mantan Wali Kota Dumai Zulkifli AS, sosok pemimpin ideal untuk Indonesia ialah kolaborasi Jokowi-JK yang mencerminkan kepemimpinan tegas, jujur dan istiqomah (haluanriaupress.com)

Di Jakarta, Komunitas Pedagang Kaki Lima (PKL) Jakarta juga membuat deklarasi untuk menyatakan dukungan terhadap pencalonan Jokowi sebagai presiden dalam pilpres 2014. Deklarasi itu diadakan di Posko Relawan Merah Putih, di jalan Cik Di Tiro 10, Menteng, Jakarta. Hampir 100 orang PKL hadir dalam deklarasi itu. Mereka merupakan anggota PKL Paguyuban Kota Tua, PKL Rusunawa Tambora, PKL Jembatan 5, serta PKL Pasar Senen (news.detik.com)

Di Bogor, ratusan warga yang menamakan diri Masyarakat Bogor 
Raya (MBR) menyatakan dukungannya untuk Jokowi. Mereka menyatakan kebulatan tekad siap mendukung Jokowi menjadi Presiden RI melalui aksi sejuta tanda tangan di halaman Gedung PPMKP, Kecamatan Ciawi, Kabupaten Bogor. Ketua MBR, Nursiwan berpendapat bahwa aksi sejuta tanda tangan ini merupakan bentuk spontanitas reaksi atas penunjukan Jokowi sebagai Capres PDI-P. Mereka menyatakan diri siap mengawal Jokowi sebagai presiden pilihan baru rakyat meskipun mereka bukan kader maupun simpatisan dari PDI-P. Dukungan terhadap Jokowi muncul karena mereka merasa bahwa Jokowi adalah pemimpin yang lahir dari rakyat dan mau melayani rakyat. Sehingga meskipun Jokowi merupakan capres usungan PDI-P, tapi sebagai rakyat kecil yang bukan dari orang parpol, mereka akan merasa puas, karena tokoh yang mereka idolakan diberi kesempatan maju (indonesia-baru.liputan6.com)

Komunitas nelayan di Indonesia juga siap mendukung Jokowi-JK. Mereka membentuk Gerakan Nelayan Sahabat Jokowi-JK. Gernas Jokowi-JK meliputi nelayan Gebang Kabupaten Cirebon, DPD HNSI Jawa Barat, DPC HNSI Karawang, Bekasi, Subang, Indramayu, Kabupaten Cirebon, Kota Cirebon, Pangandaran dan Garut. Dukungan dari nelayan lain berasal dari Serikat Nelayan Tradisional (SNT), Front Nelayan Bersatu (FNB), Serikat Nelayan Indonesia (SNI), Serikat Tani Nelayan (SETAN), Paguyuban Nelayan Kota Tegal (PNKT), Paguyuban Nelayan Mina Santosa, Pengurus Koperasi Perikanan/KUD Mina, Asosiasi Nelayan Saya Sumitra (ANESTRA), Forum Komunikasi Kelompok Usaha Bersama (KUB) dan Himpunan Nahkoda dan ABK Kapal Perikanan Indonesia (HIMNAKAPI) (www.republika.co.id). Para Nelayan mendukung Jokowi karena berbagai visi dan misi Jokowi segaris dengan keinginan nelayan Pantura. Mereka berharap potensi kelautan dan lahan pertanian bisa tergali. Selama ini nasib nelayan dan petani di Indonesia masih butuh bantuan karena kehidupan mereka kurang mampu, harapannya kebijakan Jokowi-JK bisa merubah.

Ikatan Petani Pengendalian Hama Terpadu Indonesia (IPPHTI), Asosiasi Petani dan Nelayan Nusantara (ASTANU) dan Asosiasi Petani Pengusaha Indonesia (APPI) juga menyatakan diri mendukung calon presiden dan wakil presiden Joko Widodo Jusuf Kalla. Ketiga organisasi tersebut membuat Gerakan Jokowi untuk Petani dan Nelayan Nusantara (GJPNN). Menurut Hermanu Triwidodo, Koordinator GJPNN, terdapat lebih dari 750 ribu petani yang tersebar di 152 kabupaten dan 15 provinsi yang siap memberikan dukungan. Mereka mendukung pencalonan Jokowi karena Jokowi dipandang memiliki karakteristik yang diinginkan petani yaitu sakti, budi, bakti. Pertanian Indonesia membutuhkan pemimpin yang punya komitmen untuk mengangkat harkat dan martabat kaum petani. Saat ini, pemerintah membuat kekeliruan dengan mengabaikan petani. Petani seharusnya menjadi subyek utama pembangunan sehingga kedaulatan pangan terwujud dan potensi pertanian nusantara dari Sabang sampai Merauke yang beragam dapat terajut. Jokowi pemimpin petani dan nelayan yang tepat karena memliki karakter pribadi yang nguwongke, sederhana, apa adanya tidak dibuat-buat, rendah hati dan mau mendengar tapi berani dan tegas mengambil keputusan (bisnis.liputan6.com). 
Di Yogyakarta dan sekitarnya, masyarakat mendeklarasikan gerakan gotong royong mendukung Jokowi atau disingkat Gong Jokowi di titik nol kilometer depan kantor pos besar Yogyakarta. Puluhan masyarakat yang tergabung di Gong Jokowi ini berasal dari beberapa elemen masyarakat dari Kabupaten Bantul, Sleman, Kulonprogo, Gunungkidul, Kota Yogyakarta, Kabupaten, Magelang, Temanggung Purwokerto, dan Klaten. Deklarasi dilakukan sebagai bentuk semangat gotong royong mereka mendukung Jokowi sebagai Capres. Mereka mengklaim bahwa gerakan mereka ini adalah gerakan murni masyarakat pendukung Jokowi dan bukan partai politik. Menurut masyarakat Yogyakarta, Jokowi merupakan sosok yang cocok memimpin Indonesia 2014 mendatang. Track record Jokowi sebagai pemimpin Jakarta dan Surakarta telah membuktikan bahwa Jokowi adalah sosok pemimpin yang mau dan bisa bekerja. (republika.co.id)

Di Bali, relawan Aliansi Masyarakat Sipil untuk Indonesia Hebat (Almisbat) mendeklarasikan dukungannya terhadap pencalonan Joko Widodo. Menurut Wayan Tirja, Koordinator Almisbat Bali, mereka mendukung Jokowi karena Jokowi adalah seorang pemimpin yang tidak saja mau mendengarkan rakyat, tetapi juga mau bekerja sepenuh hati untuk kepentingan rakyat (m.tribunnews.com).

Di Kota Ambon, Maluku, komunitas pemuda dan mahasiswa Pela Gandong, mengelar aksi deklarasi mendukung Jokowi, sebagai calon presiden tahun 2014. Dukungan datang dari berbagai elemen masyarakat yang terdiri dari kelompok buruh, Pedagang kaki lima, serta kelompok kaum miskin kota yang tergabung dalam aliansi rakyat merdeka. Mereka mendukung pencalonan Jokowi dan karena diianggap mampu mensejahterahkan masyarakat di masa mendatang (indonesia-baru.liputan6.com).

Di Papua, relawan yang mengatas namakan relawan Honai Jokowi-JK, mendeklarasikan dukungannya untuk memenangkan pasangan calon Presiden Jokowi Widodo di Kabupaten Mimika. Deklarasi relawan pemenangan JokowiJK, diadakan di posko Honai Jokowi-JK. Menurut Anastasia Tekege, koordinator tim relawan Honai Jokowi-JK, relawan yang dibentuk dalam wadah tim Honai Jokowi-JK, merupakan relawan-relawan yang terdorong secara sukarela untuk membantu Jokowi-JK dalam memenangkan Pilpres 2014. Relawan yang ada di Papua kebanyakan dari kaum muda yang merupakan jurnalis, pekerja LSM, pegawai negeri sipil, dan juga masyarakat adat setempat. Mereka mendukung Jokowi karena Jokowi merupakan orang kecil dan programprogram yang dicanangkan pasangan Jokowi-JK merupakan program yang disukai dan dianggap mampu dalam menjalankan roda pembangunan Bangsa Indonesia kedepannya (www.salampapua.com).

\section{Kebijakan Populis Jokowi}

Seperti yang telah disinggung sebelumnya bahwa Jokowi dipilih oleh mayoritas rakyat Indonesia karena Jokowi dinilai sebagai pemimpin yang memiliki gaya kepemimpinan populis. Berdasarkan hal tersebut maka perlu diketahui kebijakan populis seperti apa yang ditawarkan oleh Jokowi.

Menurut Burhanuddin Muhtadi, Direktur Eksekutif Indikator Politik, dalam tiga tahun pertama pemerintahannya, Jokowi justru harus 
mengambil kebijakan yang tidak populis. Ada tiga pekerjaan rumah yang perlu diselesaikan Jokowi diawal kepemimpinannya yaitu pertumbuhan ekonomi yang kurang berkualitas, naiknya defisit anggaran, infrastruktur yang terbengkalai dan membengkaknya subsidi bahan bakar minyak (BBM) yang tidak tepat sasaran. Hal ini akan memaksa Jokowi untuk membuat kebijakan yang tidak populis (news.liputan6.com).

Untuk mengatasi hal tersebut, paling tidak ada ada empat kebijakan yang akan dilakukan oleh Jokowi di awal kepemimpinannya. Pertama adalah perbaikan sistem birokrasi dan perizinan investasi. Jokowi-JK akan memangkas prosedur perizinan investasi agar semua proses bisa berjalan dengan cepat. Jokowi berjanji kepada para investor akan mengurangi subsidi BBM, memperbaiki infrastruktur, dan menggelar reformasi birokrasi besar-besaran. Kedua, adalah mengubah Rencana Pembangunan Jangka Menengah Nasional (RPJMN) 2015-2019. RPJMN yang disusun oleh pemerintahan Presiden Susilo Bambang Yudhoyono (SBY) belum memasukkan visi-misi Jokowi-JK. Karenanya, Jokowi harus melakukan intervensi korektif. Ketiga adalah reformasi pendidikan. Jokowi akan mengubah aturan wajib belajar 9 (Sembilan) tahun menjadi 12 (dua belas) tahun. Sektor pendidikan direncanakan juga akan bebas biaya pungutan dengan adanya realokasi anggaran. Saat ini dari 240 juta populasi Indonesia, hanya 4 juta yang sekolah sampai SMA. Keempat, perbaikan penerimaan negara. Jokowi akan mengejar sumber penerimaan negara dari pajak maupun non pajak (finance.detik.com).

\section{Gerakan Melawan kemiskinan}

Kemiskinan merupakan masalah utama yang harus dihadapi oleh para pemimpin populis. Mereka mendapat dukungan masyarakat karena dianggap mampu menyelesaikan persoalan kemiskinan yang diderita oleh rakyat kecil. Ada dua opsi yang dapat dilakukan oleh pemimpin populis dalam rangka mengatasi kemiskinan tersebut. Opsi pertama adalah dengan memberikan uang dan subsidi besarbesaran kepada masyarakat miskin. Opsi kedua adalah dengan menciptakan lapangan pekerjaan. Opsi pertama biasanya dilakukan oleh pemimpin populis irasional. Pemimpin irasional lebih suka mengambil jalan pintas untuk menyelesaikan masalah. Dalam rangka menyelesaikan masalah kemiskinan, pemimpin irasional akan memberikan uang, subsidi besarbesaran. Hal ini tentu akan menimbulkan masalah serius di masa yang akan datang yaitu akan menyebabkan kemerosotan keuangan negara karena dipergunakan untuk subsidi.

Sementara itu, pemimpin rasional biasanya melakukan kombinasi diantara kedua opsi tersebut. Pemimpin rasional akan memberikan subsidi secara hatihati dan sekaligus berupaya menciptakan lapangan pekerjaan. Dengan terciptanya lapangan pekerjaan, masyarakat akan memiliki kemampuan daya beli sehingga mereka dapat memenuhi kebutuhan hidup mereka.

Jokowi sebagai pemimpin populis cenderung akan memilih opsi kedua. Jokowi tetap memberikan subsidi kepada masyarakat Indonesia sekaligus berupaya menciptakan lapangan pekerjaan. Kebijakan subsidi Jokowi tertuang dalam program Kartu Indonesia Pintar (KIP) dan Kartu 
Indonesia Sehat (KIS). Bagi Jokowi, pendidikan dan kesehatan merupakan bidang yang perlu menjadi prioritas. Apabila masyarakat Indonesia pintar dan sehat maka mereka akan menjadi manusia yang produktif yang berguna bagi pembangunan bangsa.

Sasaran program KIP adalah anakanak yang kurang mampu dalam pembiayaan sekolah. Mereka akan mendapatkan bantuan biaya dari mulai tingkat SD hingga SMA. Anak-anak Indonesia yang memiliki KIP bisa sekolah sampai SMA dan SMK baik di sekolah negeri atau swasta (indonesiabaru.liputan6.com). Selain wajib belajar 12 tahun, Jokowi juga menyiapkan beasiswa bagi siswa-siswi yang tidak mampu dan berprestasi untuk melanjutkan studi ke jenjang kesarjanaan. Jokowi juga akan meningkatkan program magang kerja bagi siswa-siswi serta mahasiswa agar mereka memiliki ketrampilan praktis yang lebih baik. Jokowi berjanji akan mendayagunakan dana pendidikan 20 $\%$ dalam APBN untuk menjalankan program Indonesia Pintar.

Sementara itu, program KIS juga menjadi prioritas karena Jokowi meyakini bahwa jika warga sehat maka mereka akan mampu bekerja maksimal untuk warganya. Program KIS ini mendapatkan kritik dari beberapa politikus. Ada kekhwatiran bahwa program KIS akan tumpang tindih dengan program Jaminan Kesehatan Nasional (JKN) dan Badan Penyelenggara Jaminan Sosial (BPJS). Menurut Rieke Diah Pitaloka, salah seorang dari Tim Pemenangan Jokowi, sistem yang merupakan implementasi dari UU Sistem Jaminan Sosial Nasional (SJSN) dan UU (BPJS) harus disiapkan terlebih dahulu. Sistem ini akan mengoreksi "kesalahan" JKN. Salah satunya, terkait prinsip portabilitas, yang jadi salah satu prinsip utama dalam prinsip SJSN, terutama Jaminan Kesehatan Sosial. Dengan prinsip portablilitas itu, seharusnya jaminan kesehatan tidak boleh bersifat kedaerahan. Jaminan kesehatan sosial yang wajib dilakukan negara harus bersifat nasional, bukan kedaerahan. Namun demikian, bukan berarti pemerintah daerah tidak boleh memberikan jaminan kesehatan bagi masyarakatnya. Pemerintah daerah tetap dapat memberikan jaminan kesehatan kepada masyarakat didaerahnya sebagai komitmen politik. Akan tetapi, negara juga bisa melakukannya dengan memberikan peningkatan manfaat berupa peningkatan manfaat pelayanan dan fasilitas kesehatan.

Mengenai sumber anggaran yang akan dipergunakan untuk merealisasikan Kartu Indonesia Sehat (KIS) tersebut, akan ada dua pilihan. Pertama, dengan mengalihkan bahan bakar minyak ke gas tanpa perlu menaikkan harga BBM serta melakukan penghematan listrik. Dengan demikian akan terjadi penghematan sebesar Rp 70 triliun. Pilihan kedua, dengan menaikkan tax ratio dari $12 \%$ menjadi $14 \%$. Menurut Rieke, dengan menaikkan 2\% pajak yang dihasilkan dari seluruh barang dan jasa yang dihasikan di dalam negeri akan tercipta penerimaan baru dalam APBN sebesar Rp 150 triliun. Sementara, menurut hitungan Tim Jokowi, anggaran kesehatan yang dibutuhkan ialah sebesar Rp 95 triliun. Dengan demikian pemasukan dana baru dari salah satu pilihan tersebut sudah dapat terpenuhi untuk menutupi anggaran dana kesehatan (nasional.kompas.com).

Selain fokus pada program subsidi pendidikan dan kesehatan, kebijakan populis Jokowi lainnya adalah 
menciptakan lapangan pekerjaan. Untuk itu, Jokowi berjanji akan mencari investor sebanyak-banyaknya dan mendorong investasi ke daerah-daerah terutama ke provinsi dengan tingkat kemiskinan besar. Investasi tidak boleh terkonsentrasi di Jawa dan Sumatera saja. Kepada para investor, Jokowi berjanji akan mengedepankan kebijakan yang ramah pasar dengan fokus pada peningkatan kemampuan tenaga kerja melalui pendidikan, reformasi birokrasi, konstruksi infrastruktur dan mendorong investasi energi (sp.beritasatu.com). Kebijakan tersebut harus ditempuh oleh Jokowi dengan harapan akan ada banyak investor yang menanamkan investasinya dan lapangan pekerjaan baru akan tercipta di Indonesia.

Selain meningkatkan jumlah investor, Jokowi juga berjanji akan memperbaiki infrastruktur di daerah terpencil. Dengan demikian, akan ada banyak lapangan pekerjaan baru yang dibuka di daerah yang dapat menyerap tenaga kerja. Terkait dengan upah tenaga kerja, Jokowi mengklaim bahwa kebijakannya akan pro terhadap pengupahan buruh. Hal tersebut pernah dilakukannya ketika menjabat sebagai Gubernur DKI Jakarta. Jokowi merupakan gubernur pertama yang mau menaikkan upah hingga $44 \%$ (pemilu.tempo.co).

Jokowi juga ingin menjadikan ekonomi kreatif (knowledge economy) sebagai tulang punggung perekonomian nasional. Menurut Jokowi, ekonomi kreatif merupakan salah satu sektor perekonomian penting yang perlu dikembangkan untuk meningkatkan pendapatan rakyat. Ada dua hal penting yang diamati oleh Jokowi terkait ekonomi kreatif. Pertama, Jokowi melihat bahwa ekonomi kreatif di Indonesia didominasi oleh generasi muda usia kerja yang tidak masuk sektor kerja formal, tetapi membangun basis ekonomi melalui kreasi dan inovasi yang dimilikinya. Kedua, Jokowi melihat bahwa dengan kekayaan budaya Indonesia yang sangat beragam dan didukung oleh tingginya populasi orang muda, bangsa Indonesia seharusnya bisa menjadi pengekspor ekonomi kreatif terbesar di dunia. Untuk mencapai tujuan tersebut pemerintah harus memberikan perhatian khusus melalui pendidikanpendidikan dan keterampilan yang mendukung kreasi dan inovasi generasi muda Indonesia, serta memfasilitasi melalui berbagai program ekonomi kreatif untuk mendorong generasi muda Indonesia masuk dalam industri ekonomi kreatif. Menurut Jokowi, bidang-bidang pada ekonomi kreatif yang perlu ditekankan adalah musik, animasi, seni pertunjukan, video dan desain. Selama ini, ruang-ruang ekonomi kreatif tersebut belum mendapat dukungan penuh dari pemerintah. Jika pemerintah memberikan dukungan penuh, maka ekonomi kreatif bisa dikembangkan secara optimal (www.republika.co.id).

Jika program KIP dan KIS berjalan dengan baik serta lapangan pekerjaan tercipta secara besar-besaran maka dapat diharapkan Indonesia akan mampu mengatasi masalah kemiskinan yang telah mengakar dalam. Jokowi harus mampu menghasilkan manusiamanusia Indonesia yang produktif sehingga mereka bisa bekerja dan memenuhi kebutuhan hidup mereka tanpa harus bergantung pada subsidi pemerintah. Penderitaan rakyat harus segera diakhiri dan semuanya tersebut sangatlah bergantung pada kebijakankebijakan yang akan dibuat oleh Jokowi sebagai pemimpin populis baru Indonesia. 


\section{Kesimpulan}

Tulisan ini menyimpulkan bahwa dalam rangka memperoleh dukungan masyarakat untuk mencapai kekuasaan, paling tidak ada tiga strategi yang dilakukan oleh Jokowi. Pertama, Jokowi mengandalkan prestasi kerja. Keberhasilan-nya merubah kota Solo dan Jakarta menjadi lebih baik merupakan modal dasar bagi Jokowi untuk menarik dukungan rakyat Indonesia terhadap dirinya. Kedua, Jokowi menggunakan PDI-P sebagai kendaraan politiknya menuju pencalonan presiden RI 2014. Selanjutnya, Jokowi membangun koalisi dengan partai politik lainnya seperti Partai Nasdem, PKB dan Hanura. Jokowi juga membangun koalisi dengan masyarakat non partai yang tergabung dalam relawan Jokowi. Para relawan ini tertarik memberikan dukungan kapada Jokowi karena mereka kecewa dengan SBY. Kehadiran Jokowi di pentas politik nasional memberikan harapan baru kepada masyarakat kecil yang selama ini terabaikan oleh pemerintah. Ketiga, Jokowi mengepankan kebijakan populis yang sangat hati-hati. Jokowi berencana akan memberikan subsidi di bidang pendidikan dan kesehatan. Program ini dikenal dengan program KIP dan KIS. Dengan menjalankan program KIP dan KIS diharapkan masyarakat tidak khwatir lagi akan keberlangsungan hidup mereka. Selain itu, Jokowi juga akan membuka lapangan pekerjaan baru bagi masyarakat. Hal ini dimungkinkan karena Jokowi telah berjanji kepada para investor akan mengadopsi kebijakan yang ramah pasar. Dengan demikian, banyak peluang investasi akan tercipta dan masyarakat dapat memiliki penghasilan Dengan memiliki penghasilan, masyarakat bisa mencukupi kebutuhannya tanpa harus bergantung terlalu dalam kepada subsidi pemerintah. Berdasarkan ketiga strategi yang digunakan oleh Jokowi tersebut maka tulisan ini mengkategorikan Jokowi sebagai pemimpin populis rasional.

\section{Daftar Rujukan}

Knight, Alan. 1998. "Populism and Neopopulism in Latin America, Especially Mexico", Journal of Latin American Studies, Vol. 30, No. 2, (Cambridge University Press, May).

Roberts, Kenneth M. 2007. "Latin America's Populist Revival”, SAIS Review, Vol. XXVII No. 1 (Winter-Spring).

Sianipar, Imelda Masni Juniaty. 2011. Kebangkitan Populisme di Amerika Latin. Tesis. Program Studi Hubungan Internasional, Universitas Gadjah Mada, Yogyakarta.

Weyland, Kurt. 2001. “Clarifying a Contested Concept: Populism in the Study of Latin American Politics", Comparative Politics, Vol. 34, No. 1, (Oktober).

www.pemilu.com/profil/jokowi/. Diakses 4 November 2014.

http://news.liputan6.com/read/710305/jokowi-relokasi-warga-ria-rio-ke-rusunpinus-elok-rampung. Diakses 4 November 2014.

Dengan.Rusun.Jokowi.Buka.Peluang.Kehidupan.Lebih.Baik, http://megapolitan.kompas.com/read/2014/02/06/2042403/. Diakses November 2014 
Siapa Jokowi \& JK. http://microsite.metrotvnews.com/jokowi-jk/profile. Diakses 4 November 2014.

Pendukung.Demokrat.Golkar.Gerindra.Pilih.Jokowi.Jadi.Presiden. http://nasional.kompas.com/read/2013/12/01/1710467/. November 2014.

Daud Anselmus Jokowi Dimata Pengamat Asing, http://www.tempokini.com/2014/05/jokowi-dimata-pengamat-asing/.

Diakses 4 November 2014.

Deklarasi tim relawan Jenggala Center Aceh untuk Jokowi-JK berjalan tertib. http:/ / lintasgayo.co/2014/06/20/deklarasi-tim-relawan-jenggala-center-acehuntuk-jokowi-jk-berjalan-tertib. Diakses 8 November 2014.

13 Relawan Pendukung Jokowi-Jusuf Kalla kuatkan Tim Pemenangan. http://posaceh.com/index.php/sosok/item/392-13-relawan-pendukungjokowi-jusuf-kalla-kuatkan-tim-pemenangan Diakses 4 November 2014.

Pendukung Jokowi-JK di Aceh Deklarasikan Relawan Jenggala. http:/ /aceh.tribunnews.com/2014/06/21/ pendukung-jokowi-jk-di-acehdeklarasikan-relawan-jenggala. Diakses 8 November 2014.

ini-daftar-relawan-jokowi-jk-di-sumut. http://medan.tribunnews.com/2014/06/05/. Diakses 4 November 2014.

Deklarasi Masyarakat Pendukung Jokowi. http:/ /haluanriaupress.com/index.php?option=com_content\&view=article\&id =12611:deklarasi-masyarakat-pendukung-jokowi\&catid=70:halaman12\&Itemid=80 Diakses 4 November 2014.

http:/ / news.detik.com/read/2014/06/02/172959/2597573/1562/komunitaspedagang-kaki-lima-jakarta-deklarasi-dukung-jokowi-jk?9922022 Diakses 4 November 2014.

http:/ /indonesia-baru.liputan6.com/read/2023215/sejuta-tanda-tangan-warga-bogordukung-jokowi-presiden Diakses 4 November 2014.

Komunitas Nelayan dan Petani Dukung Jokowi-JK http://www.republika.co.id/berita/pemilu/beritapemilu/14/07/06/n8adtm-komunitas-nelayan-dan-petani-dukung-jokowijk Diakses 4 November 2014.

Tiga Organisasi Petani dan Nelayan Dukung Pasangan Jokowi-JK.

http:/ / bisnis.liputan6.com/read/2059909/tiga-organisasi-petani-dan-nelayandukung-pasangan-jokowi-jk Diakses 4 November 2014.

Dukung Capres, Puluhan Masyarakat DIY Dirikan Gong Jokowi. http://www.republika.co.id/berita/nasional/jawa-tengah-diynasional/13/11/24/mwrcsm-dukung-capres-puluhan-masyarakat-diy-dirikangong-jokowi Diakses 4 November 2014.

Almisbat Bali Deklarasi Dukungan untuk Jokowi-JK. http:/ / m.tribunnews.com/pemilu-2014/2014/06/22/almisbat-bali-deklarasidukungan-untuk-jokowi-jk. Diakses 8 November 2014. 
Dukungan Jokowi Terus Mengalir Dari Masyarakat Sebagai Capres .http://indonesiabaru.liputan6.com/read/2020143/video-dukungan-jokowi-terus-mengalirdari-masyarakat-sebagai-capres-2014. Diakses 4 November 2014.

Relawan Honai Siap Menangkan Jokowi-JK di Mimika. http://www.salampapua.com/fokus-mimika/191-relawan-honai-siapmenangkan-jokowi-jk-di-mimika. Diakses 8 November 2014.

Jokowi Diminta Berani Ambil Kebijakan Tak Populis. http://news.liputan6.com/read/2121242/jokowi-diminta-berani-ambilkebijakan-tak-populis . Diakses 4 November 2014.

Setelah Dilantik, Ini 4 Kebijakan Ekonomi Prioritas Jokowi-JK. http:/ / finance.detik.com/read/2014/08/27/134014/2674038/4/setelahdilantik-ini-4-kebijakan-ekonomi-prioritas-jokowi-jk. Diakses 4 November 2014.

Ini Kebijakan Jokowi Jika Jadi Presiden. http://sp.beritasatu.com/home/ini-kebijakanjokowi-jika-jadi-presiden/55383. Diakses 4 November 2014.

Jokowi Perkenalkan Kartu Indonesia Sehat dan Pintar di Medan.

http:/ /indonesia-baru.liputan6.com/read/2061274/jokowi-perkenalkan-kartuindonesia-sehat-dan-pintar-di-medan. Diakses 4 November 2014.

Ini Visi dan Misi Andalan Jokowi, Kartu Indonesia Pintar. http://www.republika.co.id/berita/pemilu/hot-politic/14/06/15/n77phf-inivisi-dan-misi-andalan-jokowi-kartu-indonesia-pintar. Diakses 4 November 2014.

Ini Penjelasan Timses Jokowi soal Sumber Anggaran Kartu Indonesia Sehat. htttp://nasional.kompas.com/read/2014/06/19/1937223/Ini.Penjelasan.Tims es.Jokowi.soal.Sumber.Anggaran.Kartu.Indonesia.Sehat. Diakses 8 November 2014.

Jokowi Siapkan Kartu Indonesia Sehat dan Pintar. http:/ / pemilu.tempo.co/read/news/2014/06/15/269585214/Jokowi-SiapkanKartu-Indonesia-Sehat-dan-Pintar. Diakses 4 November 2014.

Timses: Jokowi Ingin Ekonomi Kreatif Jadi Tulang Punggung Perekonomianhttp://www.republika.co.id/berita/pemilu/hotpolitic/14/06/16/n78pdg-timses-jokowi-ingin-ekonomi-kreatif-jadi-tulangpunggung-perekonomian. Diakses 8 November 2014. 